\title{
ВИЗНАЧЕННЯ ОСНОВНИХ ТЕХНОЛОГІЧНИХ ПАРАМЕТРІВ ВИГОТОВЛЕННЯ ПЕСАРІЇВ (СУПОЗИТОРІЇВ ВАГІНАЛЬНИХ) ДЛЯ ПІДГОТОВКИ РОДОВИХ ШЛЯХІВ ПЕРЕД ПОЛОГАМИ
}

Вступ. Однією з актуальних проблем сучасної медичної науки і практики є збереження здоров'я жінок репродуктивного віку. Зменшення травматизму м'яких тканин під час пологів, безумовно, залежить перш за все від раціонально і дбайливо проведених пологів. Проте важливу роль у цьому відіграє і підготовка родових шляхів. Раціональна підготовка родових шляхів з урахуванням особливостей гістологічної будови стінки піхви повинна передбачати застосування лікарських засобів, здатних підвищувати тонус еластичних і колагенових волокон, що стимулюють утворення глікогену. Крім того, важливу роль відіграє лікарська форма препарату, яку використовують для подібних цілей, тому в процесі розробки лікарського засобу було обрано песарії (супозиторії вагінальні). До складу лікарського препарату введено як активні фрармачевтичні інгредієнти гіалуронову кислоту і фрітокомплекс $\mathrm{CO}_{2}$ екстрактів календули, алое та зеленого чаю, що володіють усіма необхідними властивостями для зменшення ризику виникнення розривів м'яких тканин.

Мета дослідження - визначити основні технологічні параметри виготовлення песаріїв (супозиторіїв вагінальних) для підготовки родових иляхів перед пологами із вмістом гіалуронової кислоти і фрітокомплексу $\mathrm{CO}_{2}$ екстрактів.

Методи дослідження. Під час досліджень використовували фрармако-технологічні методи.

Результати й обговорення. У результаті використання мікроскопічного методу аналізу вивчили розчинність гіалуронової кислоти у воді очищеній, дослідили структурно-механічні властивості песаріїв залежно від температури проведення технологічного процесу. Окрім цього, встановлено температурний режим виготовлення песаріїв $(40,0 \pm 2,0){ }^{\circ} \mathrm{C}$ на підставі одержаних результатів здійсненого термогравіметричного аналізу. 3 метою визначення температури охолодження зразків вивчали їх стійкість до руйнування, в результаті чого з'ясовано, що дану стадію виготовлення песаріїв варто проводити при температурі $10-15^{\circ} \mathrm{C}$ упродовж 20 хв.

Висновки. Виконано дослідження з визначення основних технологічних параметрів виготовлення песаріїв (супозиторіїв вагінальних) для підготовки родових шляхів перед пологами із вмістом гіалуронової кислоти і фрітокомплексу $\mathrm{CO}_{2}$ екстрактів. Обґрунтовано раціональний шлях введення активних фрармацевтичних інгредієнтів у лікарську фрорму. Гіалуронова кислота розподіляється в основі за типом емульсії, а $\mathrm{CO}_{2}$ екстракти розподіляються за типом розчину. Визначено вплив на якісні характеристики песаріїв таких чинників, як температура виготовлення, дозування та охолодження супозиторної маси.

КЛЮчОВІ СЛОВА: пологи; травматизація під час пологів; фармако-технологічні дослідження; necapiï.

ВСТУП. Однією з актуальних проблем сучасної медичної науки і практики є збереження здоров'я жінок репродуктивного віку. Це стосується як прегравідарної підготовки, так і ведення пологів, вибору оптимальної тактики при пологах, профрілактики можливих ускладнень.

Зменшення травматизму м'яких тканин під час пологів, безумовно, залежить перш за все від раціонально і дбайливо проведених пологів. Проте важливу роль у цьому відіграє і підготовка родових шляхів [1].

(с) Г. М. Мельник, Т. Г. Ярних, І. В. Герасимова, 2021.
Здатність тканин піхви до розтягування, повне відкриття шийки матки та її еластичність забезпечують вільне проходження плода по родових шляхах, і від повноцінного процесу "розтягнення - цілісність - відновлення" також залежить відсутність розривів тканин під час пологів.

Раціональна підготовка родових шляхів 3 урахуванням особливостей гістологічної будови стінки піхви повинна передбачати застосування лікарських засобів, здатних підвищувати тонус еластичних і колагенових волокон, що стимулю- 
ють утворення глікогену, а також підтримують необхідне захисне середовище.

Комплексність дії може визначатися полікомпонентними препаратами, які об'єднують гідратуючі елементи, естрогеноподібну дію, стимулюють утворення глікогену і васкуляризацію тканин, зміцнюють матрикс сполучної тканини, а також мають антисептичну дію в поєднанні з місцевим імуномодулюючим впливом [2].

Таким комплексним засобом збалансованої дії, що має всі перераховані вище ефекти, можуть бути песарії, що являють собою поєднання гіалуронової кислоти (ГК) із фрітокомплексом $\mathrm{CO}_{2}$ екстрактів календули, алое та зеленого чаю [3].

Гіалуронова кислота, що входить до складу песаріїв, є полісахаридом із високим ступенем гідратування. Це складова частина міжклітинного матриксу, в тому числі й сполучної тканини. Завдяки даній властивості ГК здатна транспортувати антисептики і біологічно активні речовини в більш глибокі шари підлеглих тканин, утворювати гелеподібну субстанцію, яка забезпечує місцевий захист тканин [4].

За рахунок значної гідратації ГК виникають ефректи набухання і протидії стисканню, внаслідок чого відбувається ефрективний опір різним механічним впливам, спрямованим на здавлювання та розрив тканин і органів. Крім того, ГК бере активну участь у васкулогенезі, місцевих імунокомпетентних процесах, діленні клітин [5, 6].

Екстракти календули, алое та зеленого чаю потужні природні антисептики. Алое також має гідратуючу дію, нормалізує рН статевих шляхів, сприяє зростанню лактофрлори [7-9].

Мета дослідження - визначити основні технологічні параметри виготовлення песаріїв (супозиторіїв вагінальних) для підготовки родових шляхів перед пологами із вмістом гіалуронової кислоти і фрітокомплексу $\mathrm{CO}_{2}$ екстрактів.

МЕТОДИ ДОСЛІДЖЕННЯ. Технологію виготовлення песаріїв було обрано з урахуванням фрізико-хімічних властивостей активних фрармацевтичних інгредієнтів (АФІ) та допоміжних речовин, їх маси і типу дисперсної системи, що повинна утворитись [10].

3 фрізико-хімічної точки зору, склад досліджуваних песаріїв (супозиторіїв вагінальних) являє собою комбіновану дисперсну систему: гіалуронова кислота розподіляється в основі за типом емульсії, а екстракти розподіляються за типом розчину.

Тому головне технологічне завдання полягає в уникненні розшарування супозиторної маси та максимально рівномірному розподілі АФІ.

Порядок введення АФІ був обумовлений фрізико-хімічними властивостями, а саме розчин- ністю ГК та $\mathrm{CO}_{2}$ екстрактів. Для обґрунтування раціонального шляху введення ГК у лікарську фороу було вивчено її розчинність у супозиторних основах, а також можливість виготовлення супозиторіїв із розчиненою у воді субстанцією.

Розчинність визначали мікроскопічним методом, що дозволяє дослідити зміну фрорми і розміру часток протягом часу. Мікроскопічний аналіз проводили з використанням лабораторного мікроскопа "Konus Academi” виробництва Італії [11].

3 метою розробки раціональної технології виготовлення песаріїв було вивчено вплив температури на реологічні параметри. Структурно-механічні властивості препарату досліджували на ротаційному віскозиметрі "BROOKFIELD HB DV-II + PRO" (США) за допомогою ротаційного адаптера із системою коаксіальних циліндрів із використанням шпинделя марки SC4-21.

Термогравіметричний аналіз було проведено на дериватографрі Q-1000 системи Ф. Паулік, І. Паулік, Л. Ефрдей. Фіксували криві Т (зміни температури), ТГ (зміни маси), дТА (диференційована крива зміни теплових есректів), ДТГ (диференційована крива зміни маси). Еталоном слугував порошок з алюмінію оксидом як інертна речовина. Маса зразків становила 200 мг [12].

Стійкість песаріїв до руйнування визначали як стійкість до руйнування за певних умов шляхом вимірювання маси, необхідної для руйнування роздавлюванням на 10 песаріях за методикою Державної Фармакопеї України.

Статистичну обробку результатів досліджень проводили згідно з методиками, наведеними у Державній Фармакопеї України.

РЕЗУЛЬТАТИ Й ОБГОВОРЕННЯ. РеЗУЛЬТаТИ проведених досліджень показали, що ГК не розчиняється в інтервалі температур технологічного процесу виготовлення супозиторіїв у досліджуваних супозиторних основах.

Установлено, що ГК необмежено набухає у воді при температурі $20^{\circ} \mathrm{C}$. У полі зору спостерігали окремі частки з одночасним набуханням утворених агломератів. Частки були прозорими, об'ємними, з уламками на гладкій поверхні. Лінійний розмір часток становив 0,5 мкм із фрормфрактором 0,7 (рис. 1).

Виготовлення песаріїв із водним розчином ГК є можливим через незначну кількість гідрофрільної фрази. Саме тому гіалуронову кислоту вводили до складу досліджуваних песаріїв за типом емульсії.

Щодо $\mathrm{CO}_{2}$ екстрактів календули, алое та зеленого чаю, то вони розчиняються в жирах, володіють гідрофобними властивостями, тому 


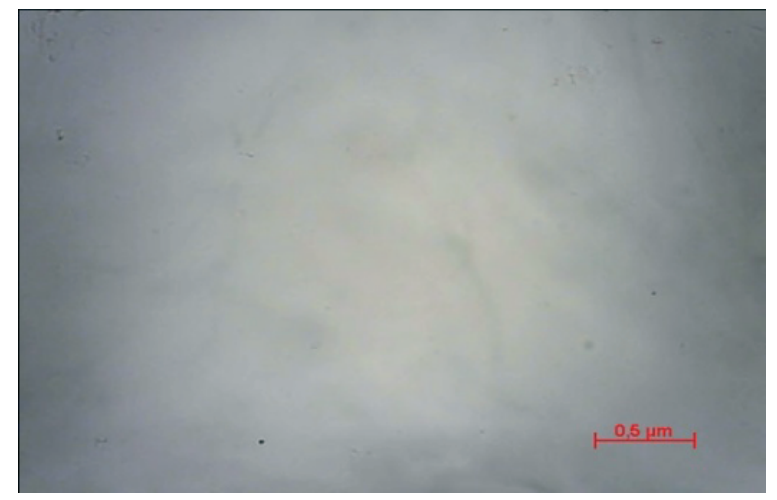

Рис. 1. Мікрофоотографрія гіалуронової кислоти у воді очищеній при температурі $20^{\circ} \mathrm{C}$

їх розчиняли у розплаві масла какао й емульсійного воску.

Для визначення температури проведення технологічного процесу і дозування супозиторної маси вивчали реологічні параметри песаріїв у межах температур 35-50 ${ }^{\circ} \mathrm{C}$.

Результати досліджень наведено в таблиці 1 і на рисунку 2.

Як свідчать дані, наведені в таблиці 1 і на рисунку 2, структурна в'язкість як супозиторної маси, так і основи мала значну залежність від температури. Зі збільшенням температури від 35 до $41^{\circ} \mathrm{C}$ значення структурної в'язкості супо- зиторної маси зменшувалося майже в 9 разів, система перебувала у стані в'язкої маси.

При температурі від 41 до $50{ }^{\circ} \mathrm{C}$ значення структурної в'язкості супозиторної маси зменшувалося майже в 4 рази, вона ставала рідкою.

Результати дослідження структурної в'язкості супозиторної основи в інтервалі температур від 35 до $41^{\circ} \mathrm{C}$ показали, що вона зменшувалася майже в 5 разів. При цьому структурна в'язкість супозиторної маси за початкової температури вимірювання $35{ }^{\circ} \mathrm{C}$ відрізнялася від структурної в'язкості основи, а за температури $50{ }^{\circ} \mathrm{C}$ - наближалася до структурної в'язкості основи при $43-45^{\circ} \mathrm{C}$.

Пов'язуючи поведінку супозиторної маси при різних температурах із технологією виготовлення песаріїв, можна обґрунтувати температурний режим їх виготовлення і дозування.

Зважаючи на те, що при температурі $\geq 45^{\circ} \mathrm{C}$ супозиторна маса має дуже низькі реологічні параметри, то при виготовленні й дозуванні песаріїв за вказаної температури ймовірна седиментація АФІ, що, у свою чергу, може призвести до неоднорідності й розшарування препарату.

При зменшенні температури до $35^{\circ} \mathrm{C}$ структурно-механічні властивості системи збільшуються, її плинність значно уповільнюється, що

Таблиця 1 - Структурно-механічні показники основи і супозиторної маси при різних температурах

\begin{tabular}{|c|c|c|c|c|c|c|c|c|}
\hline \multirow{2}{*}{ Реопараметр } & \multicolumn{8}{|c|}{ ППоказник структурної в'язкості при різних температурах } \\
\hline & $35^{\circ} \mathrm{C}$ & $37^{\circ} \mathrm{C}$ & $39^{\circ} \mathrm{C}$ & $41{ }^{\circ} \mathrm{C}$ & $43^{\circ} \mathrm{C}$ & $45^{\circ} \mathrm{C}$ & $47^{\circ} \mathrm{C}$ & $50^{\circ} \mathrm{C}$ \\
\hline \multicolumn{9}{|c|}{ Супозиторна маса } \\
\hline$\eta, м П а \times c$ & 970 & 560 & 260 & 105 & 60 & 35 & 30 & 30 \\
\hline \multicolumn{9}{|c|}{ Основа } \\
\hline ך, мПа×c & 290 & 120 & 85 & 65 & 45 & 20 & 15 & 15 \\
\hline
\end{tabular}

Примітка. $\mathrm{n}=5 ; \mathrm{P}=95 \%$.

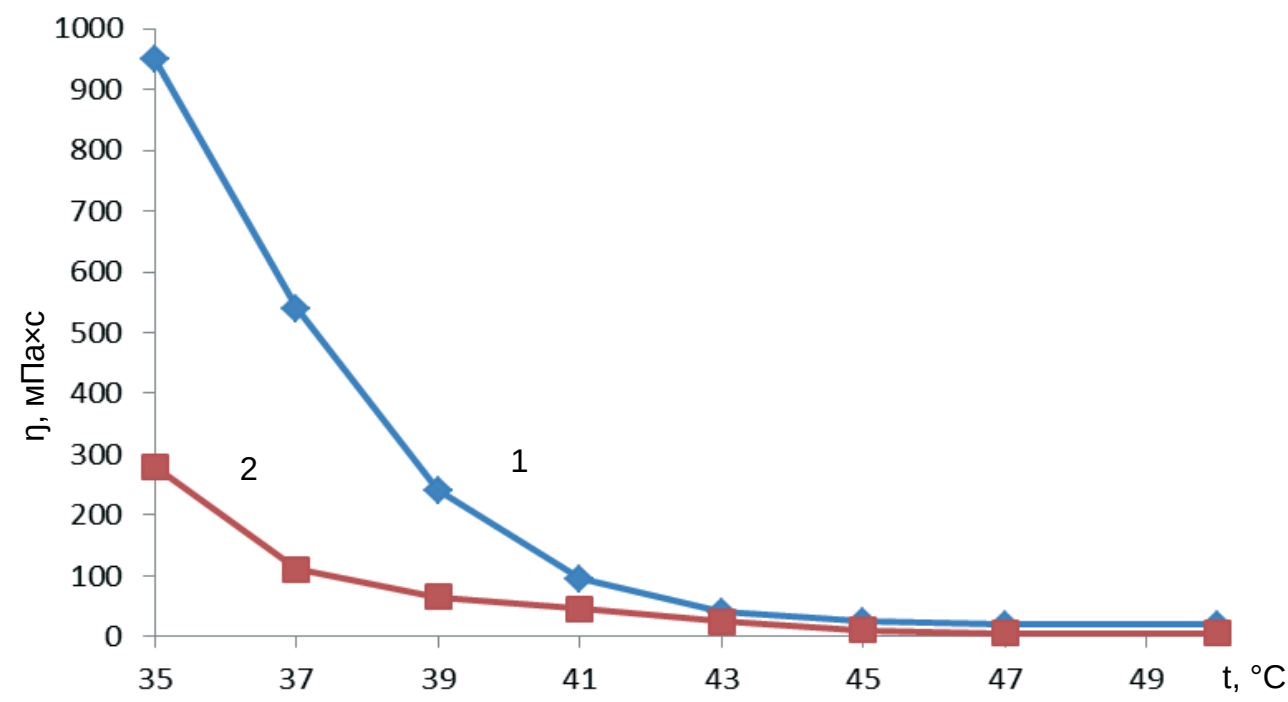

Рис. 2. Залежність структурної в'язкості супозиторної маси (1) й основи (2) від температури. 
призводить до утруднення в процесі дозування супозиторної маси. Отже, оптимальною для приготування супозиторної маси та її дозування $€$ температура $(40,0 \pm 2,0){ }^{\circ} \mathrm{C}$.

Під час проведення термогравіметричних досліджень АФІ, супозиторної основи і песаріїв було встановлено, що $\mathrm{CO}_{2}$ екстракти $є$ стабільними до температури $(50,0 \pm 1,0){ }^{\circ} \mathrm{C}$, а при температурі 52-85 ${ }^{\circ} \mathrm{C}$ втрати в їх масі становлять майже $4 \%$, за температури $210^{\circ} \mathrm{C}$ процес руйнування зразків закінчується.

Гіалуронова кислота $є$ стабільною до температури $(40,0 \pm 2,0){ }^{\circ} \mathrm{C}$, поступова втрата в її масі відбувається при температурі від 45 до $95^{\circ} \mathrm{C}$ (рис. 3).

Супозиторна основа починає плавитись при температурі $(36,0 \pm 1,0){ }^{\circ} \mathrm{C}$.

Процес розкладання досліджуваного препарату відбувається в 3 стадії. На першій стадії (до $45^{\circ} \mathrm{C}$ ) втрати вологи в масі майже не спостерігають. Друга $\left(50-125^{\circ} \mathrm{C}\right)$ і третя (до $350^{\circ} \mathrm{C}$ ) стадії характеризуються швидким процесом деструкції та значними екзотермічними еоректами.

На підставі результатів проведених досліджень можна зробити висновок, що на процеси структуроутворення при приготуванні песаріїв значно впливає температура. Термічні ефекти зразків мають подібний характер, як в індивідуальних речовинах, так і в самих песаріях.

Ще одним важливим параметром технологічного процесу є режим охолодження супозиторної маси після ії дозування в первинний пакувальний матеріал. 3 метою його визначення вивчали вплив температури охолодження супозиторної маси на стійкість песаріїв до руйнування.

Після дозування супозиторної маси в чарунки з ПВХ-плівки при $(40,0 \pm 2,0){ }^{\circ} \mathrm{C}$ зразки песаріїв охолоджували при різних температурах (від 20 до $8{ }^{\circ} \mathrm{C}$ ) до їх повного затвердіння, після чого

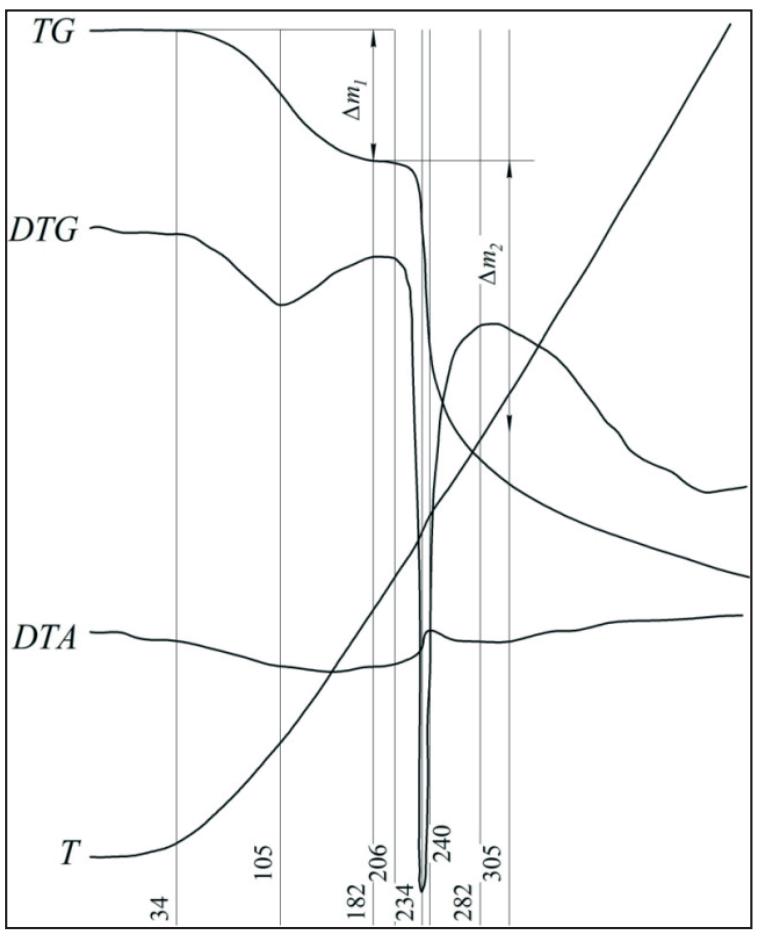

Рис. 3. Дериватограма гіалуронової кислоти.

вивчали стійкість отриманих зразків до руйнування (рис. 4).

Як видно з рисунка 4, стійкість до руйнування зразків препарату прямо залежить від температури їх охолодження. Оптимальні показники стійкості до руйнування мають песарії, які охолоджували при температурі 10-15 C. У визначеному режимі охолодження затвердіння препарату відбувається за 20 хв.

Таким чином, у результаті проведених реологічних, фрізико-хімічних і фрармако-технологічних досліджень песаріїв було визначено вплив на якісні характеристики препарату таких чинників, як температура виготовлення, дозування та охолодження супозиторної маси.

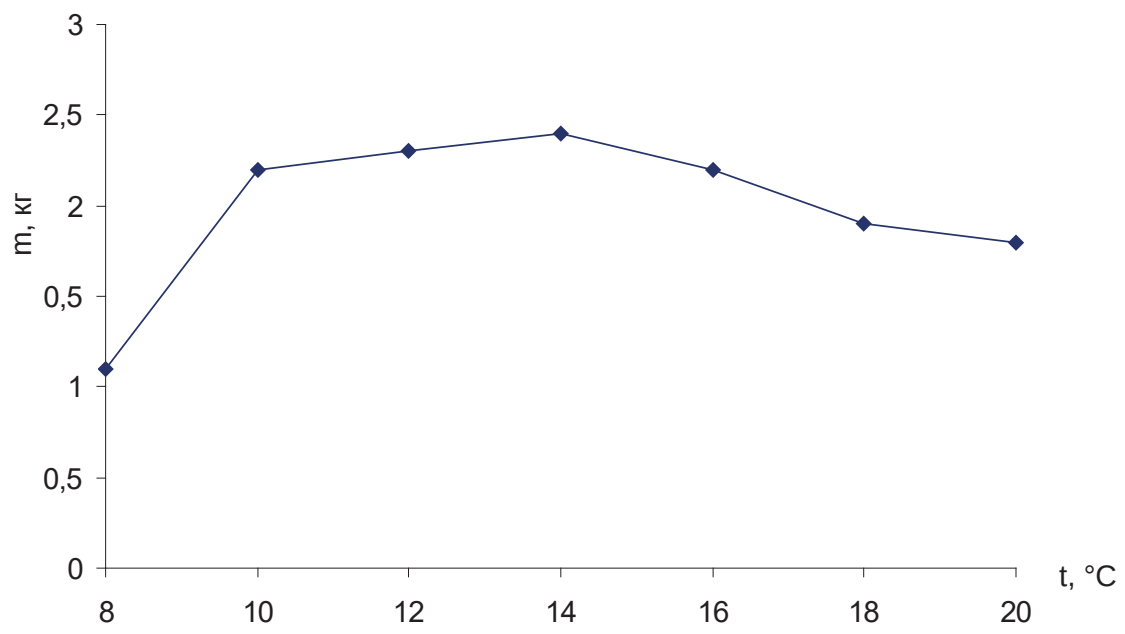

Рис. 4. Залежність стійкості до руйнування песаріїв від режиму їх охолодження. 
На підставі отриманих даних було визначено основні технологічні параметри виготовлення досліджуваного лікарського засобу:

- приготування супозиторної маси - температура $(40,0 \pm 2,0){ }^{\circ} \mathrm{C}$;

- дозування супозиторної маси - температура $(40,0 \pm 2,0){ }^{\circ} \mathrm{C}$;

- охолодження песаріїв - температура $10-15{ }^{\circ} \mathrm{C}$ протягом 20 хв.

ВИСНОВКИ. 1. Виконано дослідження 3 визначення основних технологічних параметрів виготовлення песаріїв (супозиторіїв вагінальних) для підготовки родових шляхів перед пологами із вмістом гіалуронової кислоти і фрітокомплексу $\mathrm{CO}_{2}$ екстрактів.

\section{СПИСОК ЛІТЕРАТУРИ}

1. Swati Jha. Female sexual dysfunction / Swati Jha, Ranee Thakar // European journal of Obstetrics \& Gynecology and Reproductive Biology. - 2010. - 153 (2). P. 117-123.

2. Геряк С. М. Протирецидивна терапія при запальних процесах шийки матки і піхви в жінок репродуктивного віку / С. М. Геряк // Здоров'я жінки. - 2013. № 9 (85). - C. 116-121.

3. Мельник Г. М. Теоретичне обґрунтування вибору активних фрармацевтичних інгредієнтів з метою створення засобу для застосування у підготовці до пологів / Г. М. Мельник, Т. Г. Ярних, І. В. Герасимова // Укр. біофармац. журн. - 2020. - № 4 (65). - С. 24-28.

4. Gangliang Huanga. Application of hyaluronic acid as carriers in drug delivery / Gangliang Huanga, Hualiang Huang // Drug Delivery. - 2018. - 25 (1). - P. 766-772.

5. Воловар О. С. Гіалуронова кислота: будова, фрункції, можливості застосування в комплексній терапії захворювань / О. С. Воловар, В. О. Маланчук, О. О. Кришталівська // Лікар. справа. - 2014. № 9-10. - С. 24-33.

6. Химическая модификация гиалуроновой кислоты и ее применение в медицине / Н. Н. Сигаева, С. В. Ковалев, П. В. Назаров, Р. Р. Вильданова // Вестн. Башкирского ун-та. - 2012. - 17, № 3. - С. 1220-1241.
2. Обґрунтовано раціональний шлях введення активних фрармацевтичних інгредієнтів у лікарську фрорму. Гіалуронова кислота розподіляється в основі за типом емульсії, а $\mathrm{CO}_{2}$ екстракти розподіляються за типом розчину.

3. Визначено вплив на якісні характеристики песаріїв таких чинників, як температура виготовлення, дозування та охолодження супозиторної маси.

Перспективи подальших досліджень. Ретельне вивчення технологічних параметрів виготовлення песаріїв (супозиторіїв вагінальних) для підготовки родових шляхів перед пологами дасть змогу розробити раціональну технологію виробництва екстемпорального засобу.
7. Therapeutic Potential of Calendula officinalis / Vrish Dhwaj Ashwlayan, Amrish Kumar, Mansi Verma [et al.] // Pharmacy \& Pharmacology International Journal. - 2018. - 6, Is. 2. - P. 149-155.

8. Peter Pressman. Aloe vera at the frontier of glycobiology and integrative medicine: Health implications of an ancient plant / Peter Pressman, Roger Clemens, A Wallace Hayes // SAGE Open Medicine. -2019. - 7. P. 1-8.

9. Formulation development and characterization of tea tree oil loaded ethosomes / Vijayan Venugopal, Raymond Goh, Tan Yee Ping, Tan Jia Jin // Indonesian J. Pharm. - 2015. - 27, Is. 1. - P. 44-52.

10. Melnyk Galyna. Analytical review of the modern range of suppository bases / Melnyk Galyna, Yarnykh Tatyana, Herasymova Iryna // Sys. Rev. Pharm. - 2020. 11, Is. 4. - P. 503-508.

11. Асташкина А. П. Микроскопические исследования частиц в лекарственных субстанциях : метод. указ. / А. П. Асташкина, Е. В. Плотников, Т. М. Гиндуллина. - Томск : ТПУ, 2015. - 27 с.

12. Homan M. A. Formulation and evaluation of meloxicam suppositories / M. A. Homan, H. O. Kadi // Continental J. of Pharm. Sciences. - 2011. - 5, No. 2. P. 20-24.

\section{REFERENCES}

1. Swati Jha, Ranee Thakar (2010). Female sexual dysfunction. European Journal of Obstetrics \& Gynecology and Reproductive Biology, 153 (2), 117-123.

2. Heriak, S.M. (2013). Protyretsydyvna terapiia pry zapalnykh protsessakh shyiky matky i pikhvy v zhinok reproduktyvnoho viku [Antirelapse therapy for inflammatory processes of the cervix and vagina in women of reproductive age]. Zdorovia zhinky - Woman's Health, 9 (85), 116-121 [in Ukrainian].

3. Melnyk, H.M., Yarnykh, T.H., \& Herasymova, I.V. (2020). Teoretychne obhruntuvannia vyboru aktyvnykh farmatsevtychnykh inhrediientiv z metoiu stvorennia zasobu dlia zastosuvannia u pidhotovtsi do polohiv [Theoretical substantiation of the choice of active phar- 
maceutical ingredients in order to create a tool for use in preparation for childbirth]. Ukrainskyi biofarmatsevtychnyi zhurnal - Ukrainian Biopharmaceutical Journal, 4 (65), 24-28 [in Ukrainian].

4. Gangliang Huanga, Hualiang Huang (2018). Application of hyaluronic acid as carriers in drug delivery. Drug Delivery, 25 (1), 766-772.

5. Volovar, O.S., Malanchuk, V.O., \& Kryshtalivska, O.O. (2014). Hialuronova kyslota: budova, funktsii, mozhlyvosti zastosuvannia v kompleksnii terapii zakhvoriuvan [Hyaluronic acid: structure, functions, possibilities of application in complex therapy of diseases]. Likarska sprava - Medical Business, 9-10, 24-33 [in Ukrainian].

6. Sigaeva, N.., Kovalev, S.V., Nazarov, P.V., \& Vildanova, R.R. (2012). Khimicheskaya modifikatsiya gialuronovoy kisloty i ego primenenie $v$ meditsine [Chemical modification of hyaluronic acid and its application in medicine]. Vestnik Bashkirskogo un-ta - Bulletin of Bashkir University, 17 (3), 1220-1241 [in Russian].

7. Vrish Dhwaj Ashwlayan, Amrish Kumar, \& Mansi Verma (2018). Therapeutic Potential of Calendula offi- cinalis. Pharmacy \& Pharmacology International Journal, 6 (2), 149-155.

8. Peter Pressman, Roger Clemens, A Wallace Hayes (2019). Aloe vera at the frontier of glycobiology and integrative medicine: Health implications of an ancient plant. SAGE Open Medicine, 7, 1-8.

9. Vijayan Venugopal, Raymond Goh, Tan Yee Ping, Tan Jia Jin (2015). Formulation development and characterization of tea tree oil loaded ethosomes. Indonesian J. Pharm., 27 (1), 44-52.

10. Melnyk Galyna, Yarnykh Tatyana, Herasymova Iryna. (2020). Analytical review of the modern range of suppository bases. Sys. Rev. Pharm, 11 (4), 503-508.

11. Astashkina, A.P., Plotnikov, E.V., \& Gindullina, T.M. (2015). Mikroskopicheskie issledovaniya chastits $v$ lekarstvennyih substantsiyah [Microscopic research of particles in medicinal substances]. Tomsk: TPU [in Russian].

12. Homan, M.A., \& Kadi, H.O. (2011). Formulation and evaluation of meloxicam suppositories. Continental J. of Pharm. Sciences, 5 (2), 20-24.

Г. Н. Мельник, Т. Г. Ярных, И. В. Герасимова НАЦИОНАЛЬНЫЙ ФАРМАЦЕВТИЧЕСКИЙ УНИВЕРСИТЕТ, ХАРЬКОВ

\section{ОПРЕДЕЛЕНИЕ ОСНОВНЫХ ТЕХНОЛОГИЧЕСКИХ ПАРАМЕТРОВ ИЗГОТОВЛЕНИЯ ПЕССАРИЕВ (СУППОЗИТОРИЕВ ВАГИНАЛЬНЫХ) ДЛЯ ПОДГОТОВКИ РОДОВЫХ ПУТЕЙ ПЕРЕД РОДАМИ}

\section{Резюме}

Вступление. Одной из актуальных проблем современной медицинской науки и практики является сохранение здоровья женщин репродуктивного возраста. Уменьшение травматизма мягких тканей во время родов, безусловно, зависит в первую очередь от рационально и бережно проведенных родов. Однако важную роль в этом играет и подготовка родовых путей. Рациональная подготовка родовых путей с учетом особенностей гистологического строения стенки влагалища должна предусматривать применение лекарственных средств, способных повышать тонус эластичных и коллагеновых волокон, которые стимулируют образование гликогена. Кроме того, важную роль играет лекарственная фрорма препарата, которую используют для подобных целей, поэтому в процессе разработки лекарственного средства было выбрано пессарии (суппозитории вагинальные). В состав лекарственного препарата введено в качестве активных фрармацевтических ингредиентов гиалуроновую кислоту и фритокомплекс $\mathrm{CO}_{2}$ экстрактов календулы, алоэ и зеленого чая, обладающих всеми необходимыми свойствами для уменьшения риска возникновения разрывов мягких тканей.

Цель исследования - определить основные технологические параметры изготовления пессариев (суппозиториев вагинальных) для подготовки родовых путей перед родами с содержанием гиалуроновой кислоты и фритокомплекса $\mathrm{CO}_{2}$ экстрактов.

Методы исследования. Во время исследований использовали фрармако-технологические методы.

Результаты и обсуждение. В результате использования микроскопического метода анализа изучили растворимость гиалуроновой кислоты в воде очищенной, исследовали структурно-механические свойства пессариев в зависимости от температуры проведения технологического процесса. Кроме этого, установлено температурный режим изготовления пессариев $(40,0 \pm 2,0){ }^{\circ} \mathrm{C}$ на основании полученных результатов осуществленного термогравиметрического анализа. С челью определения температуры охлаждения образцов изучали их устойчивость к разрушению, в результате чего выяснено, что данную стадию изготовления пессариев следует проводить при температуре $10-15^{\circ} \mathrm{C}$ в течение 20 мин.

Выводы. Выполнено исследование по определению основных технологических параметров изготовления пессариев (суппозиториев вагинальных) для подготовки родовых путей перед родами с содержанием гиалуроновой кислоты и фитокомплекса $\mathrm{CO}_{2}$ экстрактов. Обосновано рациональный путь введения 
активных фрармацевтических ингредиентов в лекарственную фрорму. Гиалуроновая кислота распределяется в основе по типу эмульсии, а $\mathrm{CO}_{2}$ экстракты распределяются по типу раствора. Определено влияние на качественные характеристики пессариев таких фракторов, как температура изготовления, дозирование и охлаждение суппозиторной массы.

КЛЮЧЕВЫЕ СЛОВА: роды; травматизация во время родов; фармако-технологические исследования; пессарии.

G. M. Melnik, T. G. Yarnykh, I. V. Herasymova NATIONAL UNIVERSITY OF PHARMACY, KHARKIV

\title{
DETERMINATION OF THE MAIN TECHNOLOGICAL PARAMETERS OF THE MANUFACTURE OF PESSARIES (VAGINAL SUPPOSITORIES) FOR PREPARATION OF THE BIRTH CANAL BEFORE CHILDBIRTH
}

\begin{abstract}
Summary
Introduction. One of the urgent problems of modern medical science and practice is the preservation of the health of women of reproductive age. Reducing soft tissue injuries during childbirth, of course, primarily depends on a rationally and carefully carried out childbirth. However, the preparation of the birth canal also plays an important role in this. Rational preparation of the birth canal, taking into account the peculiarities of the histological structure of the vaginal wall, should provide for the use of drugs aimed at increasing the tone of elastic and collagen fibers, which stimulate the formation of glycogen. In addition, the dosage form of the drug used for such purposes plays an important role. Therefore, in the process of developing a drug, we have chosen pessaries (vaginal suppositories). In the composition of the drug, hyaluronic acid with a phytocomplex of $\mathrm{CO}_{2}$ extracts of calendula, aloe and green tea, which have all the necessary properties to reduce the risk of soft tissue ruptures, were introduced as active pharmaceutical ingredients.

The aim of the study - to determine the main technological parameters of the manufacture of pessaries (vaginal suppositories) for the preparation of the birth canal before childbirth with hyaluronic acid and phytocomplex of $\mathrm{CO}_{2}$ extracts.

Research Methods. Pharmaco-technological methods were used during the research.

Results and Discussion. As a result of the microscopic method of analysis, the solubility of hyaluronic acid in purified water was studied. The structural and mechanical properties of the pessaries were investigated depending on the temperature of the technological process. In addition, the temperature regime for the manufacture of pessaries was set at $(40.0 \pm 2.0)^{\circ} \mathrm{C}$ based on the results obtained from the thermogravimetric analysis. In order to determine the cooling temperature of the samples, their resistance to fracture was studied, as a result of which it was established that this stage of making pessaries should be carried out at a temperature of $10-15^{\circ} \mathrm{C}$ for 20 minutes.

Conclusions. A study was carried out to determine the main technological parameters for the manufacture of pessaries (vaginal suppositories) for preparing the birth canal before childbirth containing HA and a phytocomplex of $\mathrm{CO}_{2}$ extracts. A rational route for introducing the API into the dosage form was justified. HA is distributed in the base by the type of emulsion, and $\mathrm{CO}_{2}$ extracts are distributed by the type of solution. The influence on the quality characteristics of pessaries of such factors as the temperature of manufacture, dosing and cooling of the suppository mass was determined.
\end{abstract}

KEY WORDS: childbirth; trauma during childbirth; pharmacotechnological research; pessaries.

Адреса для листування: І. В. Герасимова, Національний фрармацевтичний університет, вул. Валентинівська, 4, Харків, 61168, україна, e-mail: iryna_herasymova@ukr.net. 